\author{
PRZEMYSŁAW ŚLESZYŃSKI \\ Instytut Geografii i Przestrzennego Zagospodarowania Polskiej Akademii Nauk, Warszawa, Polska \\ Institute of Geography and Spatial Organization Polish Academy of Sciences, Warsaw, Poland
}

\title{
Propozycja podatku lokalizacyjnego od detalicznej działalności handlowej jako sposobu racjonalnego kształtowania sieci usług
}

\section{Proposition of Location Tax on Retailas a Way to Rationally Shaping the Services Network}

\begin{abstract}
Streszczenie: $W$ artykule przedstawiono koncepcję podatku w działalności sprzedażowej dla sklepów stacjonarnych, uzależnionego od wielkości powierzchni sprzedażowej i liczby ludności w odległości od miejsca sprzedaży (w skrócie: podatek lokalizacyjny). Założono, że możliwe jest kształtowanie równowagi pod względem popytu (ludność) i podaży (powierzchnia sprzedażowa) w celu uniknięcia monopolizacji rynku przez największe podmioty. Zaproponowano rozwiązanie, że im mniejsza liczba ludności z dostępem do danej lokalizacji sklepu, tym podatek powinien być niższy dla obiektów o małej powierzchni sprzedażowej oraz wyższy dla obiektów o większej powierzchni sprzedażowej. Z kolei przy coraz większej liczbie ludności wysokość podatku byłaby zrównywana dla różnych wartości powierzchni sprzedażowej. Innymi słowy, konstrukcja podatku zakłada preferencje, czyli niższy podatek dla małych sklepów w małych miejscowościach, natomiast $w$ zasadzie ich brak lub bardzo małe oddziaływanie w dużych miastach. Podatek powinien mieć korzystny wpływ na kształtowanie struktury osadniczej poprzez racjonalizację sieci handlowej.
\end{abstract}

\begin{abstract}
The article presents the concept of tax in retail activities for stationary stores, depending on the size of the sales area and the number of population at a distance from the place of sale (location tax). It was assumed that it is possible to shape the balance in terms of demand (population) and supply (sales area) in order to avoid the monopolisation of the market by the largest entities. A solution has been proposed that the smaller the population with access to a given store location, the lower the tax should be for facilities with a small sales area and higher for facilities with a larger sales area. In turn, with an increasing number of population, the tax amount would be equal to different values of the sales area. In other words, the construction of the tax implies preferences, i.e. a lower tax for small stores in small towns, but in principle their lack or a very small impact in big cities. The tax should have a positive impact on the shaping of the settlement structure and rationalising retail network.
\end{abstract}

Słowa kluczowe: dostępność przestrzenna; hipermarkety; lokalizacja działalności gospodarczej; ludność; podatek handlowy; sklepy

Keywords: business location; hypermarkets; population; spatial availability; stores; trade tax

Otrzymano: 3 września 2018

Received: 3 September 2018 
Zaakceptowano: 15 stycznia 2019

Accepted: 15 January 2019

Sugerowana cytacja/ Suggested citation:

Śleszyński, P. (2019). Propozycja podatku lokalizacyjnego od detalicznej działalności handlowej jako sposobu racjonalnego kształtowania sieci usług. Prace Komisji Geografii Przemysłu Polskiego Towarzystwa Geograficznego, 33(1), 106-116. https://doi.org/10.24917/20801653.331.8

\section{WSTĘP}

W lipcu 2016 roku Sejm RP uchwalił ustawę o podatku od sprzedaży detalicznej (Dz.U. z 2016 r., poz. 1155). Jej celem była próba ograniczenia rosnącej monopolizacji działalności handlowej przez sieci obiektów wielkopowierzchniowych, głównie hipermarketów, oraz dowartościowania mniejszych placówek handlowych, przegrywających konkurencję z sieciami supermarketów, zwłaszcza w mniejszych miejscowościach. W tle kryły się obawy związane z konkurencją sektora zagranicznego z na ogół małymi, lokalnymi przedsiębiorstwami polskimi.

Kiedy wiosną 2016 roku Ministerstwo Gospodarki ogłosiło bardziej skonkretyzowane plany wprowadzenia podatku (był on zapowiadany w programie wyborczym Prawa i Sprawiedliwości w zwycięskich wyborach parlamentarnych w 2015 roku), przez kraj przetoczyła się szeroka dyskusja, dotycząca zarówno zasadności samego podatku i jego założeń koncepcyjnych, jak też szczegółów metodyczno-fiskalnych (m.in. Benedyk, 2015; Mielcarek, 2016; Zieliński, Łaszek, 2016). Ostatecznie wybrany został wariant, w którym opodatkowana jest wartość przychodów od konsumentów indywidualnych powyżej pewnej ustalonej granicy, którą przyjęto na poziomie $17 \mathrm{mln}$ zł miesięcznie. Zastosowano też dodatkowy próg (170 mln zł), który grupę przedsiębiorstw sprzedaży detalicznej różnicował według dwóch stawek podatku $(0,8 \%$ dla podstawy opodatkowania w granicach $17-170 \mathrm{mln}$ zł oraz 1,4\% dla podstawy opodatkowania powyżej 170 mln zł miesięcznie).

Jak wspomniano, ustawa została przyjęta przez Sejm RP w lipcu 2016 roku. Ponieważ już we wrześniu 2016 roku pojawiły się wątpliwości Komisji Europejskiej co do faworyzowania na jej podstawie mniejszych sklepów, skutkujące wszczęciem procedury wyjaśniającej, najpierw resort finansów zawiesił pobór podatku od handlu detalicznego, a następnie Sejm odłożył stosowanie ustawy do końca 2018 roku.

Dyskusja nad celowością i skutkami podatku od handlu skłania do zastanowienia się nad istotą problemu. Zwolennicy tego podatku zwracają uwagę na niewspółmierność zysków przedsiębiorstw handlowych różnej wielkości, co ma związek z tzw. korzyściami skali. Te zaś zależą od możliwości sprzedaży, czyli są pochodną siły nabywczej mieszkańców. Większe korzyści skali występują więc wraz ze wzrostem koncentracji ludności (Taylor, 2000; Kaczmarek, 2010). Dlatego też zagrożenie nieuzasadnionymi przewagami konkurencyjnymi wynika nie tylko z samej wielkości obrotów handlowych danego podmiotu, ale z koncentracji sprzedaży $\mathrm{w}$ danym miejscu. W tradycyjnym handlu może ona wynikać z posiadania dużej ilości powierzchni sprzedażowej na danym obszarze w postaci jednego dużego obiektu lub odpowiednio większej ilości małych.

Powyższa kwestia przekłada się bezpośrednio na zjawisko monopolizacji handlu (Ciechomski, 2010), szkodliwe z punktu widzenia konsumentów zwłaszcza

\footnotetext{
${ }^{1}$ Ustawa z dnia 12 października 2017 r. o zmianie ustawy o podatku od sprzedaży detalicznej (Dz.U. z 2017 r. poz. 2178).
} 
w mniejszych miastach i miejscowościach (Dziewoński, Kiełczewska-Zaleska, Kosiński, Kostrowicki, Leszczycki, 1957; Wilk, 2013a; Zaremba, 2017). Z drugiej strony lokalizacja dużych obiektów w mniejszych ośrodkach nie zawsze jest opłacalna z uwagi na niski popyt (Wojdacki, Szczepankiewicz, 2008; Wilk, 2013b). Stąd też większość krajów o gospodarce wolnorynkowej stosunkowo wcześnie zaczęła prowadzić mniej lub bardziej skuteczną politykę regulacji rynków i - szerzej - politykę optymalizacyjną w tym zakresie (Bromley, Thomas, 1993; Dawson, 2012; Davies, 2013). Do najważniejszych obszarów regulacji związanych z dystrybucją można zaliczyć takie kwestie, jak: politykę konkurencji (w tym kontrolę fuzji i przejęć), zasady przepływu towarów, harmonizację podatków czy zasady ochrony konsumentów (Sagan, Skrzypek-Ahmed, Grabowiecki, 2009). W tym kontekście wymieniane są następujące regulacje dotyczące handlu (Kłosiewicz-Górecka, 2003; Sagan, Skrzypek-Ahmed, Grabowiecki, 2009):

- ustalanie wartości progowych w odniesieniu do wielkości powierzchni sprzedażowej obiektu handlowego, powyżej których obowiązują specjalne uregulowania prawne, dotyczące lokalizacji, zgód budowlanych, podatków itp.,

- ustalenia związane z czasem sprzedaży, czyli godzinami i dniami otwarcia sklepów,

- specjalne zabezpieczenia budowlano-architektoniczne i infrastrukturalne, związane z ochroną środowiska i - szerzej - wpływem na otoczenie przyrodnicze, społeczne i ekonomiczne.

Niewątpliwie próby regulowania rynku handlu wielkopowierzchniowego w Polsce mają swój związek z silną ekspansją sieci międzynarodowych po 1989 roku (Maleszyk, 1999; Taylor, 2000; Kaczmarek, 2014; Popławska, 2014) i jej nie zawsze pozytywnym wpływem na różne sfery życia, począwszy od kwestii ekonomiczno-społecznych, a na zagospodarowaniu przestrzennym kończąc. Z jednej strony napływ inwestycji zagranicznych do handlu detalicznego, w tym wielkopowierzchniowego, przyczynił się z konsumenckiego punktu widzenia do pozytywnej zmiany jakościowej, dotyczącej zwłaszcza cen, asortymentu towarów i organizacyjnych sposobów sprzedaży (Jarosz, 2002; Kaczmarek, 2010; Kucharska, 2016; Rochmińska, 2016; Maciejewski, 2017; Szymańska, 2018). Z drugiej strony podnoszona jest kwestia upadku drobnej przedsiębiorczości, wspomniana monopolizacja rynkowa, transfer zysków za granicę, homogenizacja przestrzeni, problemy komunikacyjne, wykluczenie przestrzenne z powodu złej dostępności przestrzennej do odległych centrów oraz generowanie chaosu przestrzennego (Budner, 2011; Dzieciuchowicz, 2013; Masztalski, 2014; Heffner, 2015; Wiśniewski, 2016; Jaroš, 2017; Zaremba 2017). O szczególnym znaczeniu sieci globalnych w Polsce świadczą porównania międzynarodowe (Wilk, 2004). Przykładowo zwraca się uwagę, że w 2006 roku na 22 największe transnarodowe sieci handlowe aż 14 działało w Polsce i był to najwyższy wynik wśród sześciu dużych tzw. rynków wschodzących (Argentyna, Brazylia, Chiny, Indie, Polska, Rosja), chociaż nasz kraj w tym zestawieniu jest najmniejszy (Kaczmarek, Szafrański, 2008). W sumie istnieje już bardzo bogata literatura studiów przypadków różnych miast i obszarów Polski, gdzie poruszane są pozytywne i negatywne aspekty rozwoju handlu (Jarosz, 2002; Kłosowski, 2002; Więcław, 2003; Kociuba, 2006; Namyślak, 2006; Ciok, Ilnicki, 2011; Heffner, Twardzik 2013; Kowalski, Wiśniewski, 2017).

\section{ZAŁOŻENIA I KONCEPCJA ORAZ SZCZEGÓŁY METODYCZNE}

W powyższym kontekście można zaproponować, że przeciwdziałanie monopolizacji i zrównoważony rozwój danego lokalnego rynku handlu powinien polegać na 
optymalizacji sieci sprzedaży według wskaźnika, który różnicowałby podatki nie od całości przychodów ze sprzedaży w danym kraju, ale z ich koncentracji na danym obszarze i udziale w lokalnym rynku. Innymi słowy, lokalna polityka podatkowa powinna sprzyjać użytej w tytule „racjonalizacji sieci handlu”, czyli znajdowaniu sposobów na lepsze dopasowanie ilości, wielkości i rozmieszczenia sklepów do potrzeb mieszkańców. Najbardziej pożądana byłaby sytuacja, w której przedsiębiorstwo posiada sieć placówek dość równomiernie rozmieszczonych na większym obszarze, które dla lokalnych społeczności konsumenckich stanowiłyby jedno z wielu, a nie jedyne miejsce wyboru zakupu towarów. Takie kształtowanie rynku handlu jest wręcz uzasadnione, bo pozwala zarówno na specjalizację sieci sprzedaży, np. w postaci punktów sprzedaży producenta danej marki wyrobów (tzw. sklepy firmowe), jak też nie dopuszcza do powstawania obiektów o zbyt dużej powierzchni w stosunku do istniejącej, zapobiegając efektowi monopolizacji.

A zatem aby racjonalnie kształtować sieć sprzedaży, należałoby przede wszystkim ograniczać powstawanie dużych powierzchniowo sklepów w małych miejscowościach oraz generalnie na obszarach słabiej zaludnionych, zwłaszcza wiejskich. Aby to spełnić, polityka podatkowa powinna być uzależniona od proporcji pomiędzy popytem a podażą, czyli między liczbą ludności a powierzchnią sprzedażową obiektów. Wielkość podatku należałoby zatem obliczać nie od obrotów handlowych, ale od powierzchni sprzedażowej. Dodatkowo wpływ ten powinien być proporcjonalny wykładniczo, a nie liniowo. Z drugiej strony podatek powinien być uzależniony od liczby ludności na danym obszarze. Wynika to z założenia, że w dużych skupiskach ludności wpływ większych obiektów nie jest negatywny, tak jak ma to miejsce w małych miejscowościach, w których ograniczony bezwzględny popyt limituje liczbę obiektów handlowych.

Podstawowe ogólne zasady stosowania podatku byłyby następujące:

- Podatek oblicza się od powierzchni sprzedażowej każdego obiektu oddzielnie w każdej gminie, stosując do tego stan tej powierzchni na koniec roku (lub innego okresu, względnie średnią z różnych okresów) oraz liczbę ludności.

- Podatek jest przekazywany przez przedsiębiorstwo prowadzące działalność handlową bezpośrednio na konto gminy, która ma z tego tytułu dochód budżetowy. Jeśli przedsiębiorstwo ma wiele placówek, podatek płaci odpowiednio w gminach, w których prowadzi sprzedaż.

- Proponowany podatek byłby w istocie nowym rodzajem podatku lokalnego. Stąd też wskazane byłoby, aby w przypadku obliczania podatku dochodowego możliwe było jego odliczanie od kwoty przychodu.

Jak wspomniano, koncepcja podatku zakłada, że powinien być on być większy w tych sytuacjach, gdy wielkość obiektu nie jest uzasadniona liczbą ludności i prowadzić może do monopolizacji rynku. Można zatem zaproponować następujący wzór:

$$
P=\mathrm{k} \frac{S^{2}}{\sqrt{L}}
$$

gdzie:

$\mathrm{P}$ - należny podatek,

$\mathrm{k}$ - stała,

$\mathrm{S}$ - powierzchnia sprzedaży sklepu $\mathrm{w}$ gminie $\mathrm{w} \mathrm{m}^{2}$,

L - liczba ludności w gminie. 
Takie rozwiązanie oznacza, że podatek jest proporcjonalny potęgowo do wielkości sklepu, a odwrotnie proporcjonalny (też potęgowo) do liczby ludności.

Bardzo ważne jest ustalenie stałej $k$, która decyduje o globalnej wartości podatku i osiągnięciu zakładanego celu podatkowego. Według szacunkowych obliczeń, aby kwota zrealizowanego podatku osiągnęła wartość 3 mld zł w skali całego kraju (wszystkich gmin), wartość $k$ powinna wynosić ok. 100.

\section{ZALETY I OGRANICZENIA}

Niewątpliwą zaletą przyjęcia powierzchni sprzedażowej jako podstawy opodatkowania jest uniknięcie zarzutów o preferencje bądź obostrzenia wobec niektórych grup podmiotów. Negatywne stanowisko Komisji Europejskiej wynika bowiem z argumentów dotyczących nierównego traktowania podmiotów działających na tym samym rynku. Tymczasem proponowany podatek powinien być powszechny, a ograniczanie dążenia do monopolizacji danego rynku geograficznego powinno następować poprzez nieliniowe obciążenie podatkowe, które jest proporcjonalne wykładniczo do wielkości obiektu i odwrotnie proporcjonalne (również wykładniczo) do liczby potencjalnych konsumentów. Takie rozwiązanie powinno powodować dość silne ograniczanie powstawania dużych powierzchniowo sklepów na obszarach słabiej zaludnionych, w mniejszych miejscowościach, co było główną przyczyną upadku lokalnego handlu. Innymi zaletami są: uniknięcie problemu kwalifikacji dochodów na konsumenckie i niekonsumenckie oraz wymuszenie racjonalności zagospodarowania obiektów, gdyż utrzymywanie nieefektywnej powierzchni sprzedaży okaże się mniej opłacalne. Warto też zwrócić uwagę, że dzięki proponowanemu rozwiązaniu wspierane są małe sklepy nie tylko w mniejszych miejscowościach, ale również w dużych miastach, w których nastąpił proces ich zaniku wskutek wkroczenia sieci wielkopowierzchniowych. Równocześnie na tej samej zasadzie z mniejszych miejscowości wypierane są duże sklepy, przez co zyskuje „mały” handel.

Z drugiej strony wymienić należy także wady podatku od powierzchni sprzedażowej. Po pierwsze, podatek jest homogeniczny dla wszystkich kategorii sprzedawanych produktów, a zatem nie różnicuje działalności w handlu różnymi rodzajami towarów pod względem stopy zwrotu. Ale tę homogeniczność można uzasadniać w taki sposób, że podatki i tak są płacone od dochodu, a zatem nieproporcjonalna w stosunku do powierzchni sprzedaży wielkość zysku jest już uwzględniona w redystrybucji dochodowo-podatkowej.

Realnym problemem może być wyliczanie faktycznej powierzchni sprzedażowej, przy niejasności definicji w tym zakresie ${ }^{2}$ oraz naturalnej tendencji do ograniczania jej wielkości przez przedsiębiorstwa w celu odprowadzenia jak najmniejszego podatku. Nie można przy tym wykluczyć ryzyka celowej nierzetelności czy nawet korupcji, szczególnie wrażliwej na styku samorząd-lokalni przedsiębiorcy.

${ }^{2}$ Zgodnie z ustawą z dnia 27 marca 2003 r. o planowaniu i zagospodarowaniu przestrzennym (Dz.U. z 2017 r. poz. 1073, z późn. zm.), jest to „część ogólnodostępnej powierzchni obiektu handlowego stanowiącego całość techniczno-użytkową, przeznaczoną do sprzedaży detalicznej, w której odbywa się bezpośrednia sprzedaż towarów (bez wliczania do niej powierzchni usług i gastronomii oraz powierzchni pomocniczej, do której zalicza się powierzchnie magazynów, biur, komunikacji, ekspozycji wystawowej itp.)”. 


\section{SYMULACJE PODATKU}

Poniżej przedstawiono kilkanaście symulacji dla hipotetycznych obiektów o różnej powierzchni sprzedażowej, położonych w gminach o zróżnicowanej liczbie ludności (tab. 1). W przypadku najmniejszych sklepów kwoty podatku są symboliczne. Wprowadzenie dodatkowej daniny dla obiektów takich jak kiosk oznaczałoby dla nich dodatkową opłatę roczną w wysokości kilku, kilkudziesięciu złotych. W odniesieniu do spodziewanych obrotów (przyjęto, że w uproszczeniu wynoszą one 20 tys. zł w przeliczeniu na $1 \mathrm{~m}^{2}$ powierzchni sprzedażowej) stanowiłyby one setne bądź dziesiętne części procenta przychodów. Natomiast znacznie większe skutki byłyby obserwowane w przypadku większych sklepów. Dyskont spożywczy w mniejszym mieście musiałby zapłacić już 2,5\% swoich przychodów, a hipermarket o powierzchni sprzedażowej 5 tys. $\mathrm{m}^{2} \mathrm{w}$ gminie liczącej 20 tys. mieszkańców - aż 17,7\%. W praktyce dla tego ostatniego oznaczałoby to nieopłacalność sprzedaży.

Tab. 1. Wariantowe symulacje dochodów z tytułu podatku od powierzchni sprzedażowej

\begin{tabular}{|c|c|c|c|c|c|c|}
\hline \multirow[b]{2}{*}{ Typ obiektu } & \multicolumn{3}{|c|}{ Wartości parametrów } & \multirow{2}{*}{$\begin{array}{c}\text { Roczna } \\
\text { wysokość } \\
\text { podatku (zł) }\end{array}$} & \multicolumn{2}{|c|}{$\begin{array}{c}\text { Podatek w stosunku } \\
\text { do przychodów (obrotów } \\
\text { handlowych) }\end{array}$} \\
\hline & $\mathrm{k}$ & $\begin{array}{c}\mathrm{S}(\text { powierzchnia } \\
\text { sprzedażowa, } \mathrm{m}^{2} \text { ) }\end{array}$ & L (ludność) & & $\begin{array}{c}\text { roczna wartość } \\
\text { przychodu } \\
\text { w mln zł (przy } \\
\text { założeniu } 20 \\
\text { tys. zł } / 1 \mathrm{~m}^{2} \text { ) }\end{array}$ & $\begin{array}{l}\% \text { przychodu } \\
\text { (obrotu) }\end{array}$ \\
\hline Kiosk w małej gminie & 100 & 5 & 5000 & 35 & 0,1 & 0,04 \\
\hline $\begin{array}{l}\text { Kiosk w dużym } \\
\text { mieście }\end{array}$ & 100 & 5 & 200000 & 6 & 0,1 & 0,01 \\
\hline $\begin{array}{l}\text { Mały sklep w słabo } \\
\text { zaludnionej gminie } \\
\text { wiejskiej }\end{array}$ & 100 & 30 & 5000 & 1273 & 0,6 & 0,21 \\
\hline $\begin{array}{l}\text { Duży sklep w słabo } \\
\text { zaludnionej gminie } \\
\text { wiejskiej }\end{array}$ & 100 & 200 & 5000 & 56569 & 4,0 & 1,41 \\
\hline $\begin{array}{l}\text { Duży sklep w gęsto } \\
\text { zaludnionej gminie } \\
\text { podmiejskiej }\end{array}$ & 100 & 1000 & 30000 & 577350 & 20,0 & 2,89 \\
\hline $\begin{array}{l}\text { Sklep typu dyskont } \\
\text { spożywczy w małym } \\
\text { mieście }\end{array}$ & 100 & 500 & 10000 & 250000 & 10,0 & 2,50 \\
\hline $\begin{array}{l}\text { Mały sklep w dużym } \\
\text { mieście (np. Radom) }\end{array}$ & 100 & 100 & 250000 & 2000 & 2,0 & 0,10 \\
\hline $\begin{array}{l}\text { Mały sklep w dużym } \\
\text { mieście (np. } \\
\text { Warszawa) }\end{array}$ & 100 & 100 & 1700000 & 767 & 2,0 & 0,04 \\
\hline $\begin{array}{l}\text { Hipermarket } \\
\text { w średniej gminie }\end{array}$ & 100 & 5000 & 20000 & 17677670 & 100,0 & 17,68 \\
\hline $\begin{array}{l}\text { Hipermarket } \\
\text { w średnim mieście } \\
\text { (Słupsk) }\end{array}$ & 100 & 5000 & 100000 & 7905694 & 100,0 & 7,91 \\
\hline $\begin{array}{l}\text { Hipermarket w dużym } \\
\text { mieście (Warszawa) }\end{array}$ & 100 & 8000 & 1700000 & 4908576 & 160,0 & 3,07 \\
\hline
\end{tabular}

Źródło: opracowanie własne 


\section{WNIOSKI}

Problem optymalnego (racjonalnego) rozmieszczenia sieci handlowej jest bardzo złożony, bowiem ścierają się w nim kwestie korzyści aglomeracji (skali), niekorzyści (na ogół) monopolizacji przestrzennej rynków zbytu, zgodności z interesami konsumentów (co nie zawsze wynika wprost z heterogeniczności podmiotów i obiektów, a w wielu przypadkach duża liczba podmiotów i punktów sprzedaży może sprzyjać zwyżkom cen) oraz potrzeb zapewnienia równej konkurencji podmiotów gospodarczych. Dlatego też koncepcje podatku od handlu wzbudzają żywe dyskusje oraz są przedmiotem często skomplikowanych regulacji. Nieuregulowanie organizacji handlu wielkopowierzchniowego $\mathrm{w}$ mniejszych miastach i miejscowościach będzie skutkowało narastaniem problemów związanych z depopulacją i traceniem bazy ekonomicznej miast (Śleszyński, 2017; Bilińska-Reformat, Dewalska-Opitek, 2018; Krzysztofik, Szmytkie, 2018; Śleszyński i in. 2018).

Przeprowadzone analizy wykazały, że proponowany podatek dość silnie różnicuje opłacalność sprzedaży w zależności od wielkości powierzchni sprzedażowej i liczby ludności. W przypadku małych obiektów nie ma wpływu na osiągane przychody, gdyż kwota kilku czy kilkudziesięciu złotych w skali roku jest znikoma w porównaniu do całkowitych obrotów. Natomiast istotne różnicowanie zachodzi w przypadku większych sklepów. Dla największych obiektów położonych w mniejszych miejscowościach skutki byłyby takie, że wprowadzenie podatku mogłoby doprowadzić nawet do likwidacji ich działalności z powodu zbyt wysokich kosztów funkcjonowania lub utracenia konkurencyjności względem mniejszych podmiotów.

Podane w tabeli symulacje najprawdopodobniej należałoby przeprowadzić w bardziej dokładny sposób, tak aby zarówno doprecyzować wartość wskaźnika $k$, jak też lepiej dopasować funkcję wykładniczą (lub inną nieliniową, np. logarytmiczną lub geometryczną). Miałoby to służyć jak najbardziej optymalnemu ustaleniu wielkości lokalnego rynku, na którym uzasadnione byłyby działania ograniczające niebezpieczeństwo monopolizacji rynku przez zbyt duże obiekty. Być może należałoby znaleźć bardziej skomplikowaną relację pomiędzy zmiennymi $S$ i $L$ (powierzchnia sprzedaży sklepu oraz liczba ludności w gminie), ale wówczas wzór mógłby być niezrozumiały dla większości zainteresowanych i przez to trudny w odbiorze społecznym ${ }^{3}$.

Podatek oparty na pochodnej liczby ludności w oczywisty sposób uzależniony jest od struktury osadniczej, która jest inna na obszarach peryferyjnych, w strefach otoczenia miast oraz w centrach wielkomiejskich. Gminy w Polsce są bowiem zróżnicowane pod względem typu administracyjnego (miejskie, wiejskie, miejsko-wiejskie), wielkości (powierzchni, liczby ludności), morfologii i zagospodarowania terenu, stopnia rozwinięcia systemów transportowych, dostępności przestrzennej itd. Wszystkie te czynniki wpływają bardzo silnie na rzeczywistą dostępność placówek handlowych oraz na ich zyski. Stąd też traktowanie gmin jednakowo i uwzględnianie w obliczeniach tylko liczby ludności w sztucznych, administracyjnych granicach, mogłoby dać wyniki nie do końca zgodne z zamierzonymi.

${ }^{3}$ Warto tu jednak wskazać, że stosunkowo skomplikowane działania - matematyczno-algebraiczne, trygonometryczne, $\mathrm{z}$ rachunku prawdopodobieństwa, a nawet teorii gier, skutkujące różnicowaniem różnego rodzaju opłat i podatków o charakterze masowym - są dość powszechnie stosowane w wielu dziedzinach życia społeczno-gospodarczego, np. w ubezpieczeniach, ratach kredytowych, stopach procentowych, wycenie nieruchomości, opłatach za energię itp. 
Powyższe uwarunkowania są, jak się wydaje, najpoważniejszym mankamentem propozycji podatku lokalizacyjnego. Z tego powodu można wskazywać na kierunki jego ulepszenia, związane zwłaszcza z określeniem liczby ludności, będącej w istocie „rynkiem lokalnym”. Potencjał demograficzny można byłoby przykładowo obliczać nie $\mathrm{w}$ danej gminie, ale $\mathrm{w}$ zadanym promieniu odległości. Tym samym uwzględniony zostałby niezwykle istotny czynnik dostępności przestrzennej (rozumianej tu jako możliwość osiągnięcia danego punktu sprzedaży w zadowalającym czasie i kosztach), mającej podstawowe znaczenie w organizacji lokalnego rynku i zasięgów oddziaływania obiektów. Rozwiązania tego typu są stosowane w analizie lokalizacyjnej i wyznaczaniu stref ciążenia (Plichta, 1998; Wojdacki, 2003; Kisiała, Rudkiewicz, 2017).

Drugi kierunek prac koncepcyjnych mógłby być związany z różnicowaniem podatku w zależności od rodzaju działalności sprzedażowej. Można bowiem przypuszczać, że różny asortyment towarów ze względu na swoje cechy (np. gabaryty, udział w strukturze wydatków gospodarstw domowych, okresowość popytu) ma różną stopę zwrotu i rentowności. Dotyczy to np. materiałów budowlanych, których sprzedaż z oczywistych względów wymaga znacznie większych powierzchni magazynowania, przy jednostkowo znacznie niższym zwrocie w stosunku do masy lub objętości towaru. Mogłoby to polegać na zróżnicowaniu zmiennej $k$ w podanym wcześniej wzorze na obliczenie wartości podatku. Ponadto można byłoby zastanowić się, czy nie ustalić „widełek”, czyli że podatek nie powinien być zarówno wyższy, jak i niższy od ustalonych jakichś kwot w stosunku do $1 \mathrm{~m}^{2}$ powierzchni sprzedażowej.

Trzecim kierunkiem analiz mogłoby być zastanowienie się, na ile podatek mógłby być ustalany przez gminy, czyli na ile „sztywne” powinny być wytyczne ustawowe, a na ile samorządy powinny mieć możliwość dostosowywania sposobu obliczania podatku do lokalnej specyfiki, w tym np. stosowania ulg, zwolnień itp., a nawet ustalania referencyjnej wartości zmiennej $k$, która ma największy wpływ na globalną kwotę wpływów z tytułu proponowanego podatku. Wydaje się, że samorządy powinny mieć tu pewną swobodę działania, jakkolwiek istnieje ryzyko, że mogłoby to prowadzić do nadużyć czy nawet korupcji.

Jak wspomniano we wstępie, istotą proponowanego rozwiązania jest optymalizowanie sieci sprzedaży zgodnie z pożądaną hierarchią funkcjonalno-osadniczą oraz zapobieganie monopolizacji lokalnych rynków przez największe obiekty. Wydaje się, że podatek od powierzchni sprzedażowej mógłby być dość efektywnym instrumentem wspomagającym politykę rozwoju w tym zakresie.

\section{Literatura \\ References}

Benedyk, M. (2015) (2018, 23 sierpnia). W obronie sklepów wielkopowierzchniowych. Instytut Misesa. Pozyskano z https://mises.pl/blog/2015/03/27/benedyk-w-obronie-sklepow-wielkopowierzchniowych/

Bilińska-Reformat, K., Dewalska-Opitek, A. (2018). Budowanie relacji przedsiębiorstwa handlu detalicznego z klientami w obliczu zmian demograficznych. Przegląd Organizacji, 1, 44-50.

Bromley, R.D.F., Thomas, C.J. (eds.) (1993). Retail change: Contemporary issues. London: Routledge.

Budner, W. (2011). Współczesne tendencje i determinanty lokalizacji handlu w miastach. Zeszyty Naukowe Wyższej Szkoły Handlu i Usług w Poznaniu, 21, 52-60.

Ciechomski, W. (2010). Koncentracja handlu w Polsce i jej implikacje dla strategii konkurowania przedsiębiorstw handlowych. Poznań: Uniwersytet Ekonomiczny. 
Ciok, S., Ilnicki, D. (2011). Handel detaliczny w przestrzeni dużego miasta na przykładzie Wrocławia. W: K. Marciniak, K. Sikora, D. Sokołowski (red.). Koncepcje i problemy badawcze geografii. Bydgoszcz: Wyższa Szkoła Gospodarki, 219-237.

Davies, R. (2013). Retail and commercial planning. London: Routledge.

Dawson, J.A. (2012). Retail activity and public policy. W: J.A. Dawson (ed.). Retail geography. London: Routledge, 193-235.

Dzieciuchowicz, J. (2013). Handel w przestrzeni wielkomiejskiej. Przykład Łodzi. Łódź: Wydawnictwo Uniwersytetu Łódzkiego.

Dziewoński, K., Kiełczewska-Zaleska, M., Kosiński, L., Kostrowicki, J., Leszczycki, S. (red.) (1957). Studia geograficzne nad aktywizacją małych miast. Prace Geograficzne, 9.

Heffner, K. (2015). Oddziaływanie centrów handlowych na przekształcenia strefy zewnętrznej metropolii w województwie śląskim. Prace Naukowe Uniwersytetu Ekonomicznego we Wrocławiu, 408, 95-106.

Heffner, K., Twardzik, M. (2013). Społeczne oddziaływanie nowoczesnych centrów handlowo-usługowych na małe miasta w zewnętrznej strefie aglomeracji śląskiej. Studia Ekonomiczne Uniwersytetu Ekonomicznego w Katowicach, 144, 95-108.

Jarosz, A. (2002). Miejsce hipermarketów w przestrzeni miejskiej aglomeracji. W: G. Węcławowicz (red.). Warszawa, jako przedmiot badań w geografii społeczno-ekonomicznej. Prace Geograficzne, 184, 253-264.

Jaroš V. (2017). Social and transport exclusion. Geographia Polonica, 90(3), 247-263.

Kaczmarek, T. (2010). Struktura przestrzenna handlu detalicznego: od skali globalnej do lokalnej. Poznań: Bogucki Wydawnictwo Naukowe.

Kaczmarek, T. (2014). Rozwój, struktura przestrzenna i funkcje centrów handlowych w Polsce. W: E. Klima (red.). Ludność, mieszkalnictwo, usługi - w 70. rocznicę urodzin Profesora Jerzego Dzieciuchowicza. Space-Society-Economy, 13, 247-267.

Kaczmarek, T., Szafrański, T. (2008). Poziom rozwoju i struktura przestrzenna handlu detalicznego w Poznaniu. W: A. Rochmińska (red.). Theoretical and empirical reserches on services during socio-economic changes. Space-Society-Economy, 8, 95-110.

Kisiała, W., Rudkiewicz, M. (2017). Zastosowanie diagramu Woronoja w badaniu przestrzennych wzorców rozmieszczenia i dostępności sklepów dyskontowych. Przegląd Geograficzny, $89(2), 187-212$.

Kłosiewicz-Górecka, U. (2003). Regulowanie rozwoju handlu detalicznego w Polsce i krajach Unii Europejskiej. Gospodarka Narodowa, 5-6, 97-113.

Kłosowski, F. (2002). Hipermarkety w przestrzeni handlowej miast aglomeracji katowickiej. W: J. Słodczyk (red.). Przemiany bazy ekonomicznej i struktury przestrzennej miast. Opole: Uniwersytet Opolski, 373-382.

Kociuba, D. (2006). Nowe przestrzenie handlowe Lublina. W: I. Jażdżewska (red.). Nowe przestrzenie w mieście, ich organizacja i funkcje. Łódź: Wydawnictwo Uniwersytetu Łódzkiego, 231-244.

Kowalski, M., Wiśniewski, Sz. (2017). Dostępność transportowa łódzkich centrów handlowych. Handel Wewnętrzny, 3(2), 339-357.

Krzysztofik, R., Szmytkie, R. (2018). Procesy depopulacji w Polsce w świetle zmian bazy ekonomicznej miast. Przegląd Geograficzny, 90(2), 309-329.

Kucharska, B. (2016). Sklepy dyskontowe w strukturze handlu detalicznego w Polsce. Perspektywa klienta. Handel Wewnętrzny, 3(362), 195-205.

Maciejewski, G. (2017). Formaty handlu detalicznego w Polsce w ocenie konsumentów. Studia Ekonomiczne, 316, 136-146.

Maleszyk, E. (1999). Rozwój hipermarketów, supermarketów i sklepów dyskontowych z kapitałem zagranicznym. Wiadomości Statystyczne, 44(6), 44-52.

Masztalski, R. (2014). Współczesne funkcje handlowe w wybranych małych miastach województwa dolnoślq̨skiego. Wrocław: Oficyna Wydawnicza Politechniki Wrocławskiej.

Mielcarek, J. (2016). Analiza skutków finansowych projektu ustawy Ministerstwa Finansów o podatku od sprzedaży detalicznej. Finanse, Rynki Finansowe, Ubezpieczenia, 1(79), 705-722.

Namyślak, B. (2006). Rozwój wielkopowierzchniowych obiektów handlowych we Wrocławiu. W: I. Jażdżewska (red.). Nowe przestrzenie w mieście, ich organizacja i funkcje. XVIII Konwersatorium Wiedzy o Mieście. Łódź: Uniwersytet Łódzki, 265-276. 
Plichta, G. (1998). Model Huffa jako narzędzie wspierające decyzje lokalizacyjne dużych obiektów handlowych. Zeszyty Naukowe Akademii Ekonomicznej w Krakowie, 513, 109-120.

Popławska, J. (2014). Rozwój nowoczesnych obiektów handlowych w średniej wielkości miastach w Polsce. Problemy Rozwoju Miast, 11(3), 47-52.

Rochmińska, A. (2016). Shopping centres as the subject of Polish geographical research. Geographia Polonica, 89(4), 521-535.

Sagan, M., Skrzypek-Ahmed, S., Grabowiecki, M. (2009). Zmiany w systemach dystrybucji w krajach Unii Europejskiej w latach 1990-2003. Zeszyty Naukowe WSEI. Seria Ekonomia, 1(1), 113-128.

Szymańska, A.I. (2018). Atrakcyjność centrów handlowych jako miejsc dokonywania zakupów i korzystania z oferty usługowej w opinii respondentów. Prace Komisji Geografii Przemysłu Polskiego Towarzystwa Geograficznego, 32(2), 245-254.

Śleszyński, P. (2017). Wyznaczenie i typologia miast średnich tracących funkcje społecznogospodarcze. Przegląd Geograficzny, 89(4), 565-593.

Śleszyński, P., Wiśniewski, R., Szejgiec-Kolenda, B. (2018). Demographic processes in Poland in the years 1946-2016 and their consequences for local development: Current state and research perspectives. Geographia Polonica, 91(3), 317-334.

Taylor, Z. (2000). Przekształcenia sieci handlu detalicznego i gastronomii w okresie transformacji społeczno-gospodarczej Polski. Prace Geograficzne, 175.

Więcław, J. (2003). Hipermarkety jako nowy element w strukturze przestrzennej miast Polski na przykładzie Krakowa. W: Z. Górka, J. Więcław (red.). Badania i podróże naukowe krakowskich geografów. Kraków: Polskie Towarzystwo Geograficzne, 137-146.

Wilk, W. (2004). Zachodnioeuropejskie sieci handlowe w Czechach, w Polsce i na Słowacji: podobieństwa i różnice. W: E. Jakubowicz, A. Raczyk (red.). Regionalny wymiar integracji europejskiej. Wrocław: Instytut Geografii i Rozwoju Regionalnego Uniwersytetu Wrocławskiego, 231-240.

Wilk, W. (2013a). Koncepcja sieci a geografia zorganizowanego handlu detalicznego w Polsce. Warszawa: Wydział Geografii i Studiów Regionalnych Uniwersytetu Warszawskiego.

Wilk, W. (2013b). Miasta zbyt małe na handel z dyskontem. Acta Universitatis Lodziensis Folia Geographica Socio-Economica, 15, 21-37.

Wiśniewski, Sz. (2016). Dostępność mieszkańców województwa łódzkiego do sklepów wielkopowierzchniowych. Acta Universitatis Lodziensis Folia Geographica Socio-Oeconomica, 23, 25-38.

Wojdacki, K.P. (2003). Metody określania obszarów wpływów miast jako miary ich atrakcyjności rynkowej. Zeszyty Naukowe Akademii Ekonomicznej w Krakowie, 624, 65-78.

Wojdacki, K.P., Szczepankiewicz, W. (2008). Metody pomiaru atrakcyjności handlowej miast. Zeszyty Naukowe Uniwersytetu Ekonomicznego w Krakowie, 757, 85-104.

Zaremba, M. (2017). Ochrona małych i średnich przedsiębiorców przed eksploatacją ze strony dużych podmiotów rynkowych (relacja B2b). Internetowy Kwartalnik Antymonopolowy i Regulacyjny, 6(1), 20-34.

Zieliński, M., Łaszek, A. (2016) (2018, 24 sierpnia). Dodatkowy podatek od handlu - szkodliwy i nieuzasadniony. Analiza 1/2016. Warszawa: Fundacja Obywatelskiego Rozwoju. Pozyskano z https://www.wiadomoscihandlowe.pl/wp-content/uploads/2016/01/Raport-FORPodatek-od-handlu.pdf

Przemysław Śleszyński, dr hab., prof. Instytutu Geografii i Przestrzennego Zagospodarowania PAN (IGiPZ PAN), kierownik Zakładu Geografii Miast i Ludności IGiPZ PAN; członek komitetów naukowych i problemów PAN: Badań nad Migracjami, Nauk Demograficznych, Nauk Geograficznych, Przestrzennego Zagospodarowania Kraju; przewodniczący Komisji Osadnictwa i Ludności PTG i wiceprezes PTG, członek Głównej Komisji Urbanistyczno-Architektonicznej oraz Związku Urbanistów Polskich. Od 1997 r. prowadzi badania z zakresu geografii społeczno-ekonomicznej i gospodarki przestrzennej, w tym rozwoju miast, procesów ludnościowych, przedsiębiorczości, transportu i geografii wyborczej, a także planowania przestrzennego i rozwoju regionalnego. Autor ponad 400 prac z tego zakresu, w tym około 20 monografii.

Przemysław Śleszyński, associate professor, Institute of Geography and Spatial Organization, Polish Academy of Sciences, Head of the Department of Urban and Population Studies of IGSO PAS; member of the Scientific and Problem Committees of the Polish Academy of Sciences: Research on Migration, Demographic 
Sciences, Geographical Sciences, Spatial Economy and Regional Planning; chairman of the Commission for the Settlement and Population Geography of the Polish Geographical Society and vice chairman of the PGS, member of the Main Urbanistic and Architectural Commission and the Association of Polish Town Planners. Since 1997, he has been conducting research in the field of socio-economic geography and spatial economy, including urban, population, enterprise, transport and electoral geography, as well as spatial planning and regional development. Author of over 400 works in this field, including about 20 monographs.

ORCID: 0000-0002-1369-6129

\section{Adres/address:}

Polska Akademia Nauk Instytut Geografii i Przestrzennego Zagospodarowania ul. Twarda 51/55, 00-818 Warszawa, Polska

e-mail: psleszyn@twarda.pan.pl 